\title{
TEJTERMELÉS ÖNKÖLTSÉGSZÁMÍTÁSI MODELLJE EGY VIDÉKI SZARVASMARHA TELEPEN
}

\author{
Halag Ágnes
}

\begin{abstract}
Absztrakt: Egy vidéki vállalkozás tej önköltségének vizsgálatát végeztem el, összehasonlítva a meghatározó tejtermelő gazdaságok ágazati eredményeivel három év átlagában. Feltártam az eltéréseket. Vizsgáltam az alkalmazott költségkalkulációs sémát. Megállapítottam, hogy a telepen nem alkalmazzák a változó és állandó költségek elkülönítését. Javaslatom az, hogy a költségek megkülönböztetésére különös hangsúlyt kellene fektetni, illetve évközben is vizsgálni azokat, így még idöben be lehet avatkozni a költségekbe, így a tej önköltségébe, közvetetten a jövedelem alakulására.

Abstract: I tested the first cost of milk in a rural enterprise compared to the sectoral results of decisive dairy farms in the average of three years. I discovered the differences. I examined the applied cost calculation scheme. I determined that the site does not apply the division variable and fixed costs. My suggestion is that special emphasis should be placed on the distinction between costs and these costs should be analyzed during the course of the year, thus it is possible to intervene in time so that the costs of milk can be directly related to milk costs.
\end{abstract}

Kulcsszavak: tej, önköltség, költség, tejtermelés, szarvasmarhatelep

Keywords: milk, first cost, cost, milk production, cattle farm

\section{Bevezetés}

Vizsgálatom célja, hogy bemutassam a tej önköltségének szerkezetét egy dél-alföldi szarvasmarhatelepen Mezöhegyes környékén. A terület gazdasági feltételei kedvezőek (Zsótér, 2008).

Az elmúlt évtizedekben a gazdasági és társadalmi átalakulások mentén minden termelő ágazat, így a mezőgazdaság is kereste a lehetőségeit a megváltozott körülmények között és igyekezett adottságait, meglévő erőforrásait kihasználni a hosszú távú versenyképesség fenntartása érdekében. Ebben a sokszor átláthatatlan és komplex piacgazdasági rendszerben a magyar mezőgazdaság elvesztette azt a jelentőségét, amelyet hosszú időn keresztül, hagyományosan képviselt. A '90-es évek változó politikai környezete (rendszerváltozás) következtében, a mezögazdaság leépülése miatt a szarvasmarha állomány jelentősen lecsökkent, csak a nagygazdaságok tudtak hatékonyan müködni (Nagy et al., 2005). Colman és Young szerint a hatékonyság csak relatív fogalomként értelmezhetö (Colman-Young, 1989).

Varga és munkatársai szerint Magyarország csak akkor képes szarvasmarhatenyésztését megtartani, ha az ágazat jövedelmezőségét fokozni tudja. Ez azonban csak akkor lehetséges, ha az ágazatban feltárják a rejtett veszteségeket és mindent megtesznek annak elhárítására (Varga et al., 2005). Fontosak az állattenyésztésben történö beruházások is (Zsótér-Túri, 2017), amelyeknél nem szabad megfeledkeznünk a gazdaságossági számítások jelentőségéről sem (Zsótér, 2017). $\mathrm{Az}$ ökonómiai fogalmak értelmezésében lényeges különbségek vannak, melyeket tisztázni szükségesek, hogy a szakemberek egy nyelvet beszéljenek (Nábrádi, 2005). 
$\mathrm{Az}$ állatállomány termelése mérhető természetes mértékegységben, ezek a hozamok, a pénzértékben kimutatott hozamok adják a termelési értéket. A tehenészetekben ikertermék a született borjú, melyet tejegyenértékben át kell számolni, így beleszámít a tejhozamba, $1 \mathrm{~kg}$ született borjú $=8$ liter tej. (Önköltség számítási szabályzat 2016) Az állattenyésztési ágazatok költségein belül a takarmányozás költsége a legmeghatározóbb, így a költségek elemzése során a hangsúlyt a takarmányköltségek vizsgálatára kell helyezni (Sabján-Sutus, 2009). A tejtermelés költségszerkezetét vizsgáltam meg a meghatározó tejtermelö gazdaságok 3 évi átlagában és összehasonlítottam a kiválasztott telep adataival.

\section{Anyag és módszer}

Statisztikai adatokon, elemzéseken alapuló módszerek. Ezek a módszerek azon a feltételezésen alapulnak, hogy a jövöbeli szituáció a múlttal a folyamatosság miatt valamilyen hasonlóságot mutat. $\mathrm{Az}$ adatgyüjtést interjúk segítségével, valamint módszeres megfigyeléssel végeztem. Az adatokat matematikai, statisztikai módszerek segítségével dolgoztam fel és diagramok segítségével ábrázoltam. amelyhez a MICROSOFT OFFICE EXCEL 7.0 for WINDOWS programol alkalmaztam.

A gazdaságok eredményességét javítja a pontos és naprakész számítógépes adatnyilvántartás. A vizsgált telepen a RISKA telepirányító programot használják. amely minden - a szarvasmarha tartáshoz szükséges - termelési adatot rögzít. A kff a BITWIN vállalatirányítási rendszert alkalmazza, melyböl a készlet és költséq adatokat nyertem.

\section{Eredmények és értékelésük}

A hozamok megfigyelése mellett a költségek és az árbevétel elemzése során fontos információkat kapunk, az árbevétel és a költségek különbsége adja a jövedelmet, a tejtermelés célja pedig a jövedelem növelése.

3.1.Saját vizsgálatok

A mezőgazdasági termékek közvetlen önköltségének meghatározási utókalkulációval történik, az alábbi kalkulációs sémán keresztül (Musinszki, 2012):

- Anyagköltség

- Igénybe vett szolgáltatások

- Egyéb szolgáltatások

- Személyi jellegủ ráfordítások

- Értékcsökkenési leírás

- Felhasznált befejezetlen termelés költsége

- Fenntartó üzemi költségek

- Segédüzemi költségek

- Felosztott költségek

- Le: káresemény miatt elszámolt összeg

- Összes közvetlen költség $(1+2+3+4+5+6+7+8+9-10)$

- Le: melléktermék értéke 
- Fötermék közvetlen költsége (11-12)

Az önköltségek legnagyobb részét a takarmányköltségek teszik ki. Fontos dolog az állattenyésztésben, hogy a külső környezeti tényezők, - mint pl. az időjárás közvetlenül nem éreztetik hatásukat, mint a növénytermesztésben, bár a takarmányokon keresztül indirekt módon befolyásolják az eredményeket. A tej önköltségének és értékesítési átlagárának bemutatására a 1. ábrán kerül sor.

\subsection{A tejtermelés költségszerkezetének vizsgálata}

A tej önköltségének alakulását az egyes költségnemek változása, illetve azok aránya nagymértékben meghatározza, ezért célszerü a tejtermelés költségszerkezetének elemezése. A tejtermelés önköltségének szerkezetét összehasonlítottam az országos átlaggal, 2013.-2015. évek közötti átlagot számoltam (2. ábra).

Megállapítható, hogy a vizsgált telep költség összetétele szignifikánsan eltér a tesztüzemi adatoktól. A takarmányköltség tesztüzemi átlag alapján $48 \%$-ot, a vizsgált gazdaság szarvasmarha telepén ugyanazon három év átlagában 41\%-ot tesz ki. A munkaerő költség a tesztüzemi átlag alapján 13\%, a vizsgált telepen $18 \%$.

\section{1. ábra: Tej önköltség, értékesítési átlagár, eredmény alakulása a vizsgált telepen}

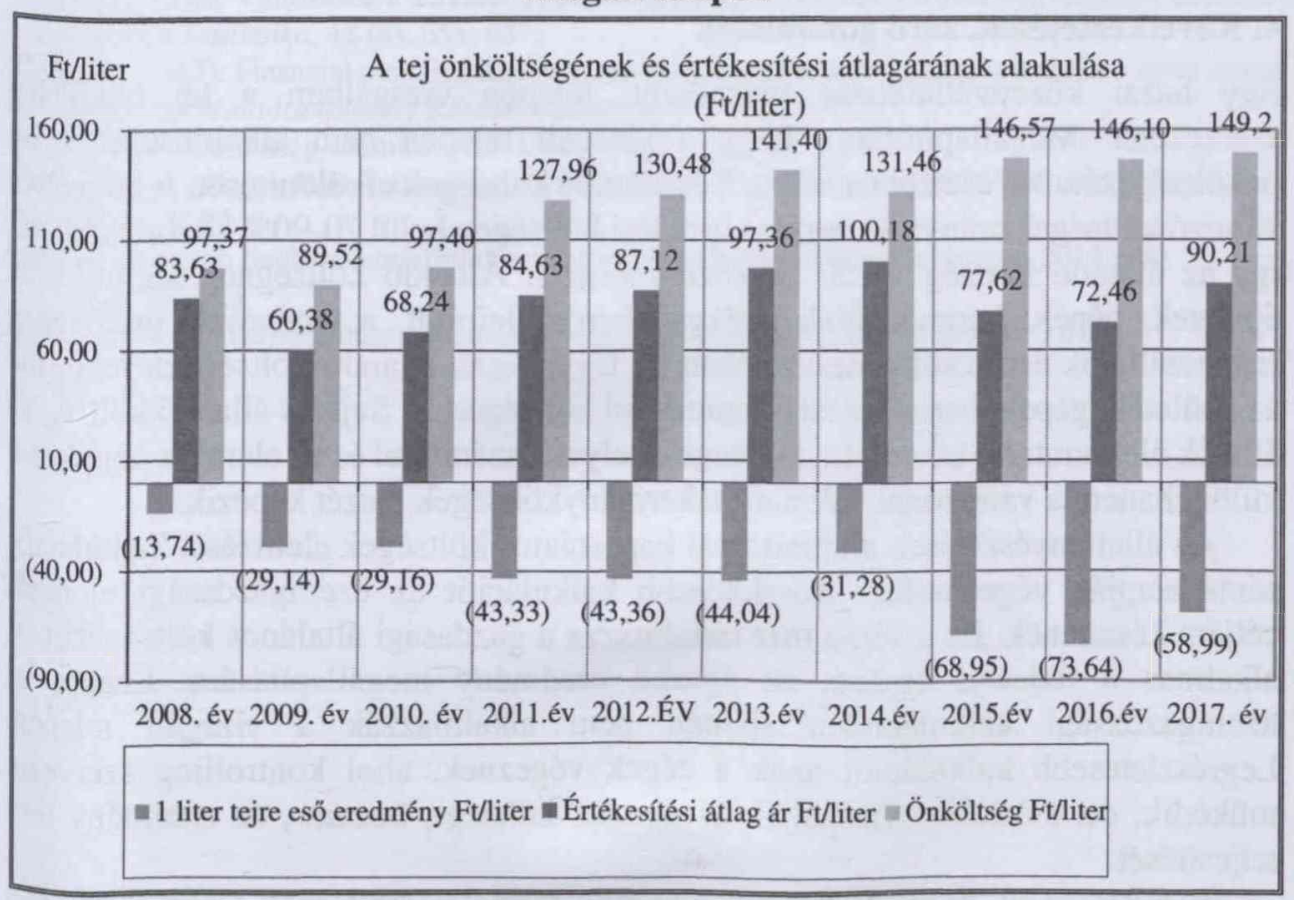

Forrás: Saját szerkesztés, üzemi adatok alapján (2018)

Kardinális kérdés a tejágazat ökonómiai vizsgálatakor a tenyészállat értékcsökkenés, amely a tesztüzemi átlag esetén 7\%, ugyanez a mutató a vizsgált telepnél $11 \%$-ot mutat a tej önköltségének szerkezetében. Az egyéb költségek nem mutatnak lényeges eltérést, a tesztüzem esetén $32 \%$, a vizsgált telepen $30 \%$. 
2. ábra: Tejelő tehéntartás költségszerkezetének összehasonlítása

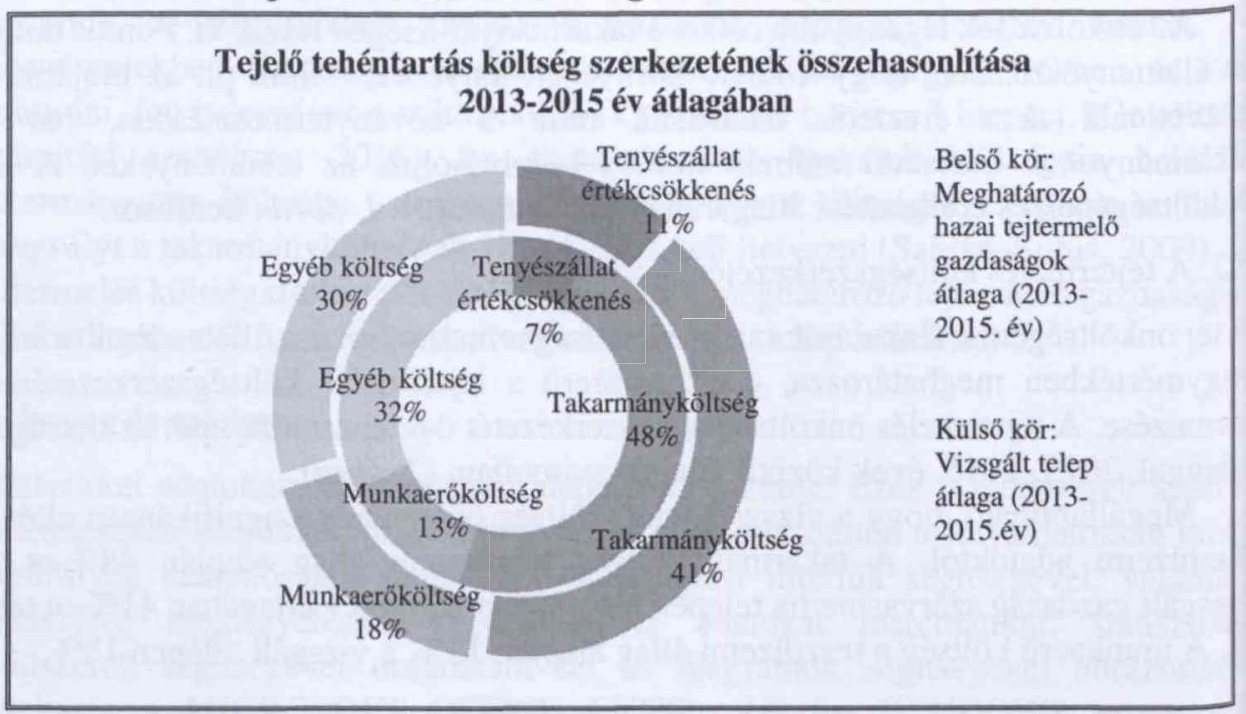

Forrás: saját szerkesztés, AKI tesztüzemi ágazati adatok és üzemi adatok alapján (2017)

\section{Következtetések, záró gondolatok}

Egy hazai középvállalkozás tehenészeti telepén vizsgáltam a tej önköltsé \& szerkezetét. Megállapítottam, hogy a vizsgált telepen nem alkalmazzák a tej önköltségszámítás esetében a változó és állandó költségek elkülönítését. A közvetleø változó költségek aránya az összes termelési költségen belül 70-90\% között változik: így az állandó költség 10-30 \% között mozog. Állandó költségnek tekintjük at épületek, gépek, berendezések értékcsökkenési leírását, a tehenészet esetében tenyészállatok értékcsökkenési leírását is. Ugyancsak állandó költségnek tekintjił az épületek, gépek, berendezések fenntartási költségeit is. Sajátos állandó költség al állatok életfenntartó takarmányköltsége, melyet a számvitel és az elemzés nem keze külön, hanem a változónak tekintett takarmányköltségek részét képezik.

Az állattenyésztéssel, állattartással kapcsolatos költségek elemzését kalkuláció séma alapján végezhetjük. Részletesebb kalkulációt az üzemgazdasági elemzé céljára készítenek. Ez a séma már tartalmazza a gazdasági általános költségeket is alkalmas a fedezeti összeg, az ágazati eredmény megállapítására. Ezeket d üzemgazdasági kalkulációkat szintén nem alkalmazzák a vizsgált telepen Legrészletesebb kalkulációt azok a cégek végeznek, ahol kontrolling szervezt müködik, ott évközben vizsgálják az ágazati költség-, hozam-, és eredmény ter teljesítését.

Javaslatom az, hogy alkalmazni kellene a termelési költségek csoportosítását termelés volumenének változása alapján, így a változó és állandó költségek jo elkülöníthetőek lennének, továbbá javaslom azokat évközben is vizsgálni, így mé! időben be lehet avatkozni a költségek visszaszorításába. 


\section{Irodalomjegyzék}

Colman, D., Young, T. (1989): Principles of agricultural economics. Cambrige University Press, Cambrige.

Magda S. (2003): A mezõgazdasági vállalkozások gazdalkodásának alapjai. Mezőgazdasági vállalkozások szervezése és ökonómiája I. Szaktudás Kiadó Ház, Budapest.

Musinszki Z (2012): Mezögazdasági számvitel, oktatási segédlet, pénzügy és számvitel alapszak, számvitel szakos hallgatók számára. Miskolc.

Nábrádi A. (2005): A gazdasági hatékonyság értelmezése napjaink mezögazdaságában. In: Jávor A. (szerk): A mezögazdaság tôkeszükséglete és hatékonysága. Debreceni Egyetem ATC AVK, 2334.

Nagy A., Popovics P., Szöllösi L. (2005): A tejtermelés termelési értéke, In: Szücs I. (szerk.): A szarvasmarha-ágazat gazdasági, szervezési és piaci kérdései. Szaktudás kiadó Ház, Budapest, $104-116$.

Sabján J., Sutus I. (2009) A mezőgazdasági vállalkozások gazdálkodásának elemzése. Szaktudás Kiadó Ház, Budapest

Sutus I. (2002) Gyakorlati számvitel a mezögazdaságban, Szaktudás Kiadó Ház, Budapest, 2002.

Varga N., Bertalanné V.E., Salamon, L. (2005): Két tejtermelő szarvasmarhatelep összehasonlító vizsgálata. Gazdálkodás, 49 (4): 27-32.

Zsótér B., Túri I. (2017): Economical calculations related to a smoking technology investment of a pork processing plant. Annals of Faculty of Engineering Hunedoara - International Journal of Engineering, 15 (4): 57-61.

Zsótér B. (2008): Változások a délkelet-alföldi Mezỏhegyes életében várossá nyilvánítását követően. Területi Statisztika, 48 (6): 651-657.

Zsótér B. (2017): Financial planning in connection with accomodation development in a sport centre. Quaestus Multidisciplinary Research Journal, 4 (11): 172-177.

Sz. n. (2016): Önköltség-számítási szabályzat. Négy-Határ 99' Kft

〈https://www.aki.gov.hu/publikaciok/publikacio/a:250/Tejpiaci+inform\%C3\%A1ci\%C3\%B3k> (2018. 02.24.)

〈https://www.ksh.hu/docs/hun/xftp/idoszaki/evkonyv/mezogazdasagi_evkonyv_2014.pdf> (2017.02.21.)

<http://www.ksh.hu/docs/hun/xstadat/xstadat_evkozi/e_oma001.html> (2017.03.16.) 